\title{
Food losses and waste in the French oilcrops sector
}

\author{
Frédéric Fine $^{1, \star}$, Jean-Louis Lucas ${ }^{1}$, Jean-Michel Chardigny ${ }^{2}$, Barbara Redlingshöfer $^{3}$ and Michel Renard ${ }^{4}$ \\ ${ }^{1}$ CETIOM 11 rue de Monceau, CS 60003, 75378 Paris Cedex 08, France \\ 2 INRA - Département Alimentation Humaine, 63122 Saint Genes Champanelle, France \\ 3 INRA, Direction Scientifique Alimentation, Mission d'anticipation Recherche/Société (MaR/S), 147 rue de l'université, \\ 75338 Paris Cedex 7, France \\ 4 INRA, UMR 1349 IGEPP INRA, Agrocampus Ouest Rennes, Université Rennes1 BP35327, 35653 Le Rheu Cedex, France
}

Received 13 January 2015 - Accepted 27 February 2015

\begin{abstract}
INRA has initiated a comprehensive approach to food loss and waste for all the plant and animal sectors, from field to distribution. In this study, all comestibles that leave the human food chain and are not recycled into animal feed are considered as losses and waste. The main French oilseed sectors are studied (rapeseed, sunflower and soya, as well as tofu). In order to identify the key sources of loss, all of the various steps in the process of the oleaginous production chain are described, from harvesting through to distribution, including storage, transport, crushing, refining and packaging. For tofu, the study also examines the chain from harvest through to distribution, including as soy milk and tofu paste. Published data are lacking; they were therefore primarily collected directly from professionals in the sectors concerned. Although oilseeds and vegetable oils are apt to have a relatively long shelf-life compared to other products, losses of vegetable oil from field to distribution are substantial (approximately $71.4 \mathrm{kT}$, equivalent to $10 \%$ of the amount consumed in France). We establish that the principal steps giving rise to losses are harvesting and refining. Total losses in French rapeseed oil, sunflower and soybean were estimated at 9.8\%, 7.0\% and 6.0\% of their respective total potential production, worth approximately 50.6, 14.3 and $6.5 €$ million and equivalent to the annual consumption of approximately 3030000,855000 and 390000 people. In the case of tofu, harvest is the most important area of loss. Total losses of tofu are equivalent to $8.2 \%$ of potential production. We discuss potential measures to improve the efficiency of the individual steps of French oilseed production.
\end{abstract}

Keywords: Oil / tofu / harvest / crushing / refining / loss

Résumé - Pertes et gaspillages dans le secteur de l'huilerie française. Une approche globale des pertes et gaspillages en alimentation humaine a été initiée par l'INRA pour l'ensemble des filières végétales et animales, du champ jusqu'à la distribution. Dans cette étude, ont été considérés comme pertes et gaspillages tous les produits consommables par l'homme qui sortent de la chaîne alimentaire humaine et ne sont pas recyclés en alimentation animale. Les principales filières oléagineuses françaises ont été étudiées (colza, tournesol et soja ainsi que le tofu). Les différentes étapes du process de la chaîne oléagineuse ont été décrites de la récolte à la distribution, en intégrant le stockage, le transport, la trituration, le raffinage et le conditionnement, afin d'identifier les étapes clés impactant les pertes. Pour le tofu, l'étude a porté également de la récolte à la distribution, en incluant la production de lait de soja et de tofu. Les données ont été collectées principalement grâce à l'expertise de professionnels, en raison du manque de données publiées. Bien que les graines oléagineuses et les huiles végétales soient adaptées à une conservation relativement longue par rapport à d'autres produits, les pertes en huiles végétales du champ à la distribution restent très significatifs (environ 71,4 kT, équivalent à $10 \%$ de la consommation d'huile en France). Il a été établi que les principales étapes impactant les pertes sont la récolte et le raffinage. Les pertes totales en huile de colza, de tournesol et de soja ont été estimées respectivement à $9,8 \%, 7,0 \%$ et $6,0 \%$ de la production potentielle d'huile en France, équivalents à 50,6, 14,3 and 6,5 M€ ou à la consommation annuelle d'environ 3030 000, 855000 et 390000 personnes. Pour le tofu, les pertes à la récolte sont les plus importantes. Les pertes totales en tofu sont equivalentes à $8,2 \%$ de la production potentielle de tofu. Des mesures visant à améliorer l'efficience du système oléagineux français à chaque étape du process sont discutées.

Mots clés : Huile / tofu / récolte / trituration / raffinage / perte

\footnotetext{
^ Correspondence: fine@cetiom.fr
} 


\section{Introduction}

This study on food losses and waste in the oil crop sector is part of a much larger study conducted in 2014 under the auspices of INRA, the French National Research Institute on Food, Farming and the Environment. As a partner in the EUproject FUSIONS ${ }^{1}$, a principal objective of which is to quantify food losses and waste in Europe, INRA asked its permanent working groups on agricultural production sectors (seven animal and five plant production sectors, one of which is for oilseed crops) to respond, for their specific sector, to the following request:

- Discuss the concept of food losses and waste as it applies to their sector.

- Indicate the incidence and determinants of food losses and waste; indicate their fate (waste management, recycling).

- Assemble the available data in order to calculate food losses and waste quantities.

- Identify issues for research, knowledge on which would support the prevention and reduction of food loss and waste.

Heretofore, the study of food losses and waste at primary production has generally been ignored in literature. The aspect of our study concerning the incidence of food losses and waste at the farm level and at immediate post-harvest stages is therefore expected to make a substantial contribution towards closing knowledge gaps.

This paper is part of a much fuller study that will be published in the course of 2015.

\section{Context and challenges}

Reducing food losses and waste is widely acknowledged as a means of meeting food system-related challenges such as global food security, global warming, the preservation of natural resources and ecosystems, access to food for those in need, and hence of fostering food system sustainability (UNEP, 2009; Lundqvist et al., 2008; Lipinsky et al., 2013). During recent years the topic of food losses and waste, estimated to amount to one third of total food production (Gustavsson et al., 2011) or one out of four calories produced (Lipinsky et al., 2013), has surged, and as a consequence has been put at the head of political and research agendas.

Literature on stating the problem and the related environmental and economic impacts has become abundant, but reliable data on food losses and waste along supply chains remain scarce. Moreover, due to varying definitions, scope and data collection methods they are often difficult to compare. Furthermore, research tends to repeatedly use a few gross estimates, notably from the 2011 FAO study (Gustavsson et al., 2011)

1 The FUSIONS project (Food Use for Social Innovation by Optimising Waste Prevention Strategies) is directed towards rendering Europe more resource-efficient by significantly reducing food waste. It is a 4-year project, running from August 2012 to July 2016. It is funded by the European Commission Framework Program 7. http://www.eu-fusions.org/ which covers the main agricultural production sectors in the main regions worldwide. Quantification initiatives at different scales (national, for example in France within a Parliamentary mission on food waste reduction ${ }^{2}$; regional, for example the EU-project FUSIONS; international, e.g. the WRI/UNEP food loss \& waste protocol ${ }^{3}$ ) have been launched to obtain harmonized data and to build a standardized quantification framework as reference.

\section{Methodology}

\subsection{Definition and system boundaries}

According to the Gustavsson et al. study for the FAO (2011), "food losses or waste are the masses of food lost or wasted in the part of food chains leading to "edible products going to human consumption." On this basis, food originally meant for human consumption but which is subsequently directed to a non-food use (feed, bioenergy, etc.) is therefore considered as food loss or waste. The FUSIONS-project employs a slightly different definition where food waste can be either edible or inedible parts of food; food that leaves the human food chain and is then used as animal feed or as bio-based material is not therefore necessarily to be considered as waste.

For the purpose of this study, food losses and waste comprises only the edible parts of food intended for human consumption which are removed from the food supply chain and which are not used for feeding animals either. Data collection nevertheless covers also the amounts of inedible parts of food (by-products, etc.) and where possible the amounts of edible parts valorized in different ways (feed, energy, compost etc.). Thus, the study provides a comprehensive analysis of the production process and the related product flows.

System boundaries of the studied sectors are set to include the following stages: primary production, post-harvest operations, processing and supplying. At the primary production stage, food losses and waste are considered to occur only from the moment when crops are ready for harvest (Fig. 1). To simplify, the expression 'food losses' will be used instead of 'food losses and waste' hereinafter.

\subsection{Choice of the species:}

While covering all sources of vegetable oil, the activity of the GROI (GRoupe filière Oléagineux Inra) focused mainly on rapeseed, sunflower and soybean. The study was coducted in two stages:

- Stage 1: rapeseed, sunflower, soybean and flax; species for which the Cetiom has the requisite expertise.

- Stage 2: olive, palm and olive oils; species for which expertise is at CIRAD and AFIDOL.

\footnotetext{
${ }^{2}$ http://www.guillaume-garot.fr/public/lettre_de_mission_G_ Garot-gaspillage_alimentaire.pdf

3 http://www.wri.org/our-work/project/food-loss-waste-protocol
} 


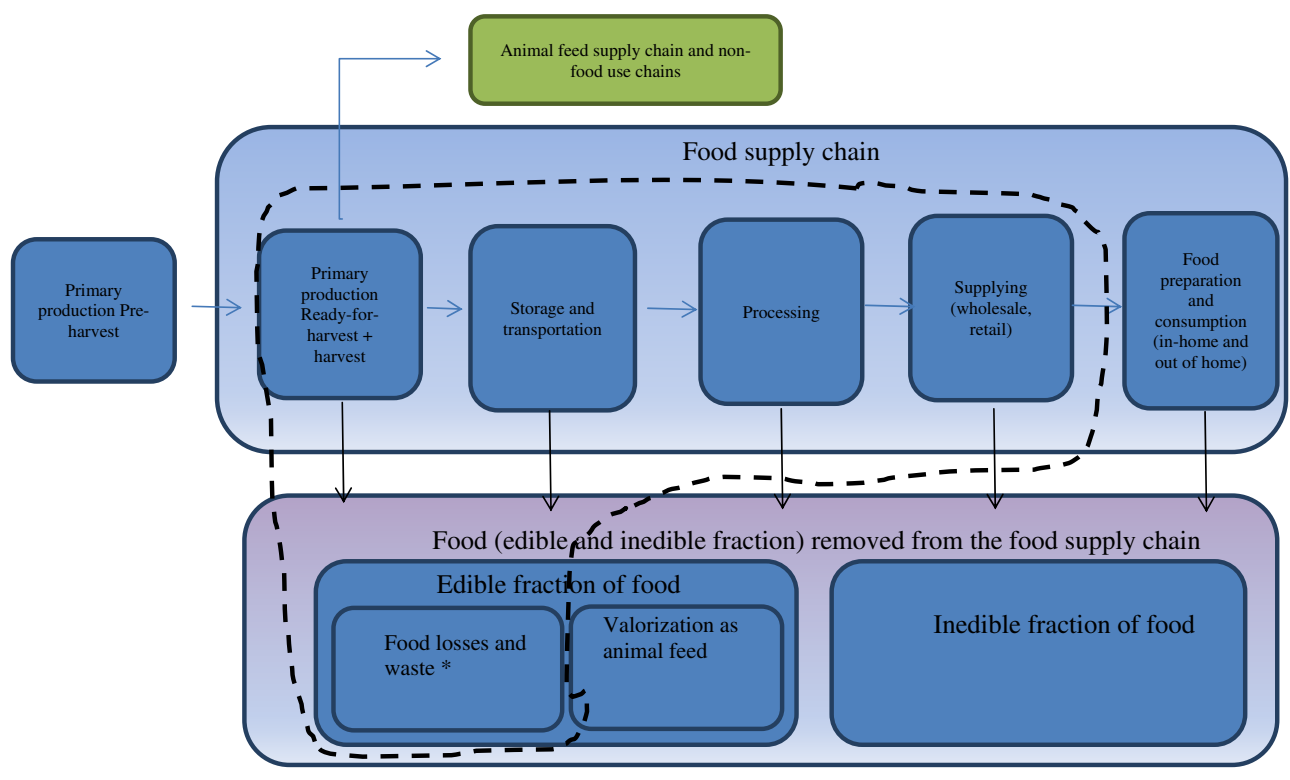

Source : authors

* Elimination or valorization except for uses as animal feed

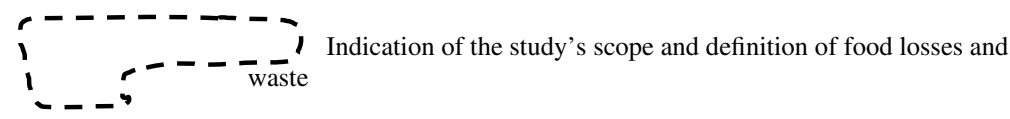

Fig. 1. Framework defining system boundaries and food losses and waste in this study.

Walnut, grapeseed, peanut oil and corn, hemp, hazelnut, mouth sunflower and mustard were not included, nor were the proteins extracted from rapeseed meal and sunflower since the use of the protein meals of these latter oilseeds as human foodstuff is rather hypothetical, which is not the case of soybeans, which are widely used in 'juice' or 'fermented juice'- type products. If necessary some species could be studied later in relation to groups in other sectors (nuts for example, could be studied along with the Fruits and Vegetables group).

Choice criteria:

For production: rapeseed and sunflower are two of the world's major oilseeds. For three decades the production of canola and double-low rapeseed varieties (low erucic acid and glucosinolate contents) has enabled the development of edible oils from rapeseed. Rapeseed has thus become the world's third largest source of vegetable oil after soy and palm (Fig. 2).

The world rapeseed crop is estimated to cover twenty million hectares (http://www.indexmundi.com/agriculture/). The leading producers in 2011 were the EU, China, Canada, India, Japan, Mexico, USA, Pakistan and Russia. While some countries such as India use rapeseed oil for cooking, in Europe it is channeled to biodiesel fuel production (approximately $75 \%$ of production) and its volume is expanding. In addition, the EU aims to increase its economic independence by substituting rapeseed for soy in animal feed.

In 2008-2009, world sunflower seed production was about 33 million tonnes, around $8.5 \%$ of the world oilseed pro-

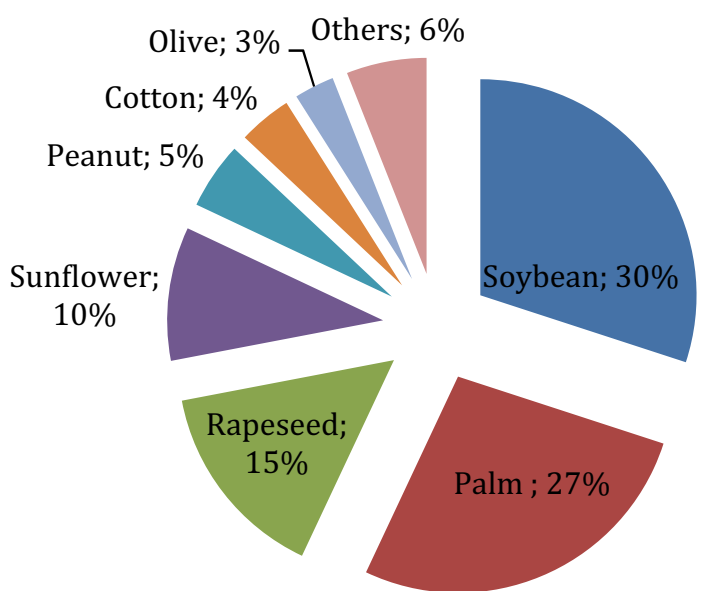

Fig. 2. Distribution of the world production for vegetable oils. Source: http://www.andines.com/IMG/pdf/marche_de_1_huile_ d_olive_et_des_olives_situation_et_perspectives.pdf.

duction (http://www.agricommodityprices.com). The leading producers are the EU, Russia, Ukraine, Argentina, USA, China, India and Turkey (Lomascolo et al., 2012). In France, three refined oils are mainly produced: rapeseed oil (960 000 t), sunflower oil (496000 t) and soybean oil (120000 t).

Olive oil production reached around 3 millions tons in 2012 and European production represented more than $70 \%$ of world olive oil production. Spain (1 347400 t), Italy $(44000 \mathrm{t})$ and Greece $(310000 \mathrm{t})$ are the main 


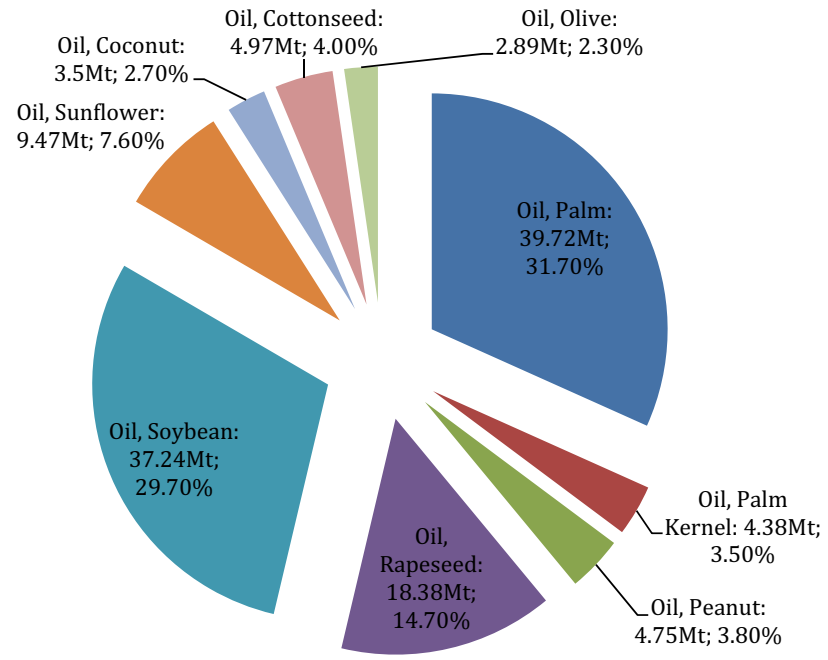

Fig. 3. World consumption of vegetable oils (2007/2008, Source of the data: www.fas.usda.gov/psdonline).

Table 1. Total vegetable oil consumption (in liter) in France (2013, Nielsen/ONIDOL data).

\begin{tabular}{cc}
\hline TOTAL & 297552800 \\
\hline Sunflower oil & 126856500 \\
Olive oil & 69687100 \\
Mixed oil & 31180800 \\
Rapeseed oil & 29455600 \\
Frying oil (unspecified species?) & 25688200 \\
Peanut oil & 6176800 \\
Grapeseed oil & 3353300 \\
Other oils & 5154400 \\
\hline
\end{tabular}

European countries for olive oil production (http://www. andines.com/IMG/pdf/marche_de_1_huile_d_olive_et_des _olives_situation_et_perspectives.pdf). The French olive oil production is close to $6000 \mathrm{t}$ per year.

For consumption: as shown in Figure 3, the world's most consummed oils are palm (31.7\%), soybean $(29.7 \%)$ and rapeseed $(14.7 \%)$. In France, the oil consumption is divided into two main sectors: food consumption (household, food industry, etc.) and industrial consumption (biodiesel, green chemistry, etc.). Total food consumption reached almost 300 millions liters in 2013 and Table 1 highlights that sunflower and olive oils were the most consumed, with 126 million liters and 69 million liters respectively (around $65 \%$ of the market). Consumption appears to be only slightly influenced by regional culinary cultures (Fig. 3; Table 1).

\section{Description of the systems}

Rapeseed, sunflower and soybean oils as well as tofu processes were outlined (Figs. 4-7).

\subsection{Oils}

\section{Oilseed harvest}

- Rapeseed harvest: for reasons of storage it is recommended that rapeseed be harvested at a $9 \%$ humidity rate. Harvesting is complicated by the fact that rapeseed is an indeterminate crop and therefore has at harvest a variable quantity of immature seeds. It is very common to see some stems and partly green pods. To avoid this difficulty, swathing is a possible alternative to harvesting winter rapeseed. But straight combining will perform better, and is more economic.

A slower speed will be needed than with wheat. The speed of the combine depends on the maturation quality of rape and on the combine equipment employed.

The sources of rapeseed losses when using a combine harvester are those of reaper assembly loss and treshing and cleaning loss.

Seed losses at the front of the combine harvester increase as the harvest is delayed; it depends on seed moisture, on the crop's sensitivity to pod dehiscence and on the pods' maturity.

Few years ago, it was recommanded to harvest rapeseed at 12 to $14 \%$ seed moisture in order to avoid seed losses at the front of the combine. Now, with the new varieties, the cracking of pods and the shedding of seeds is less important a problem. Several new varieties have a better pod strength. These cultivars become shatter resistant and the differences in fields are significantly different. Now, it has become possible to harvest at $9 \%$. At this moisture rate, threshing and cleaning in the combine is more effective (fewer losses).

In fact, to efficiently avoid losses at the front of the combine, it is preferable to work with a combine equipped with a header extension specific to rapeseed harvesting.

On the other hand, the main reason for seed loss in treshing and cleaning is the starting time of rape harvesting. Even if grains are nearly at $9 \%$, when the straw and the stems moisture is too hight, harvesting losses occur during separation, cleaning and shaking. The best results are obtained when straw moisture at the back of the combine is lower than $20 \%$.

Electronic loss monitors will not accurately measure losses at the back of the combine. They only signal increases and decrease in losses; they do not show how many tons/ha are thrown out. To obtain the level of the losses, it is necessary to measure true losses on the ground with a large metal pan. With their small diameter and their dark brown/black color, obtaining even an approximative count of the grains on the ground is very difficult.

- Sunflower harvest: sunflowers can be combined when the seed moisture is nearly at $9 \%$. Sunflowers can easily shatter if the heads are very dry. Waiting too long to harvest can result in excessive field losses.

A proper header attachment is necessary to reduce shattering losses and harvest efficiency.

A pan header which is mounted on traditional straight cut headers is the most used equipment; it is also the cheapest.

- Soybean harvest: it is recommended that soybeans be harvested at a $14 \%$ humidity rate. Direct combining harvesting is easy. The separation between grains and straw in the combine occurs without difficulty. The size and the weight of grains are clearly different compared with the straw and the pods. Cleaning by blowing air is very efficient. 


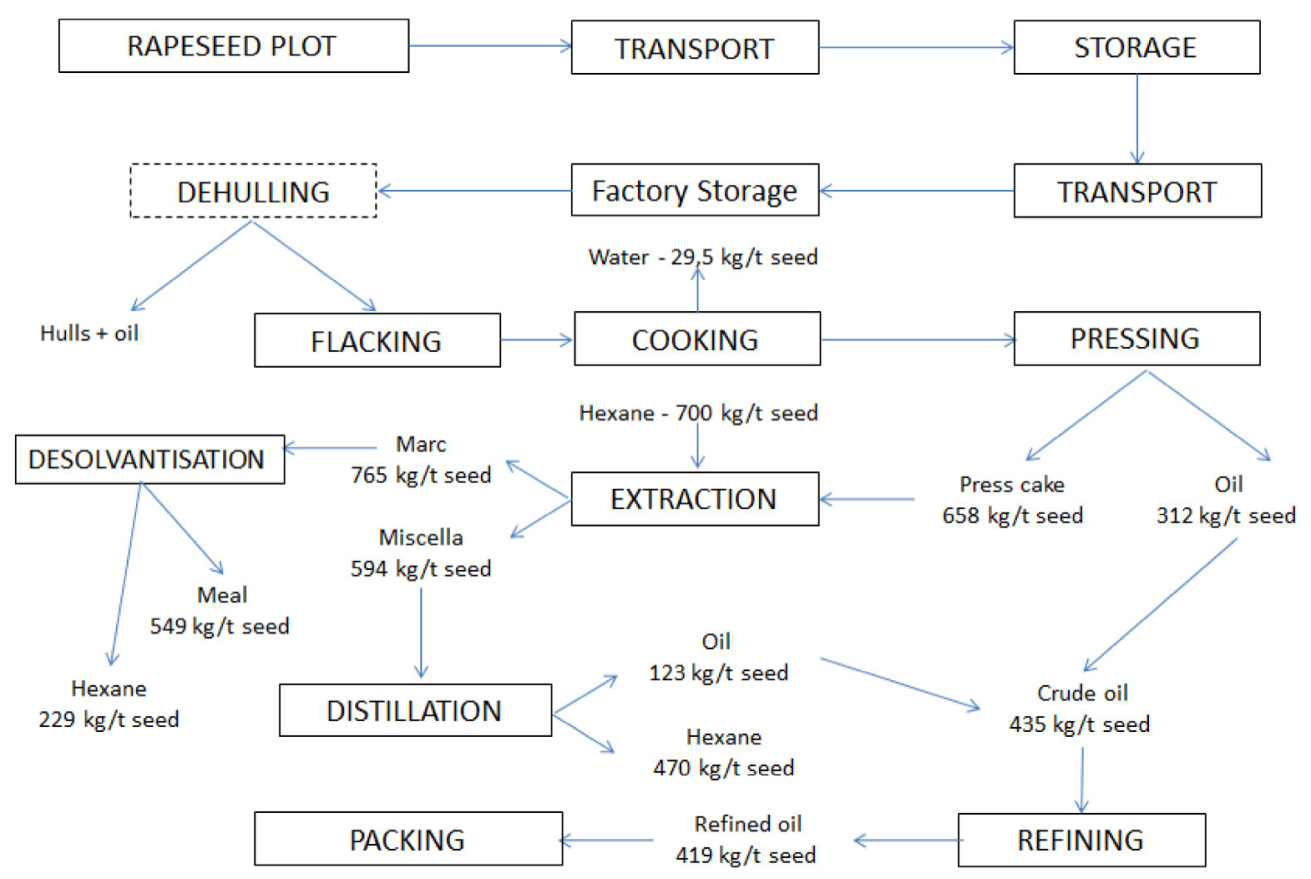

Fig. 4. Description of rapeseed crushing process with the mass balance for one ton of seeds.

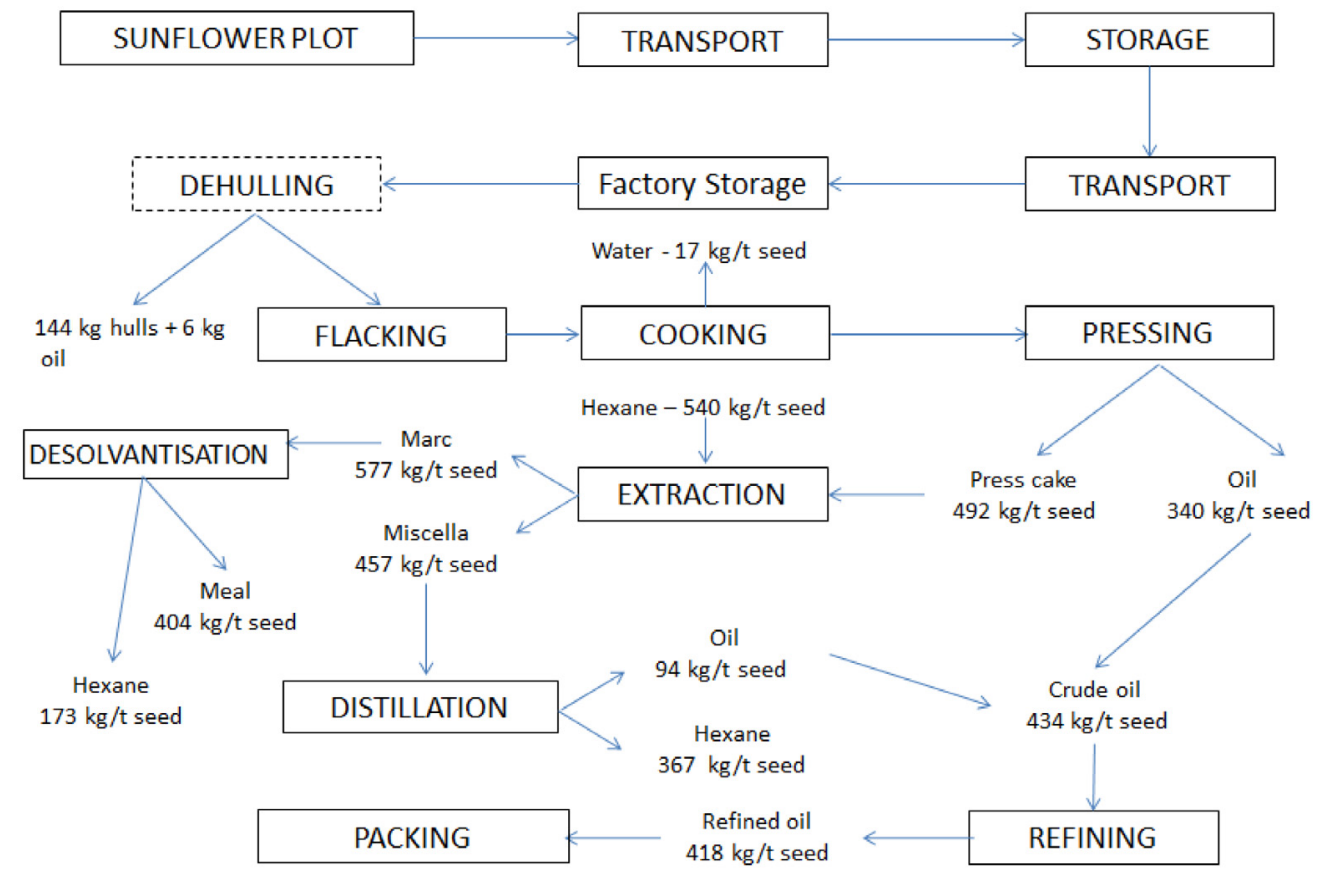

Fig. 5. Description of sunflower crushing process with the mass balance for one ton of seeds.

Pods remaining on the stubble can sometimes be a problem during the soybean harvest. The variety and the method of cultivation may result in the pods growing too close to the soil.

\section{Oilseed transportation}

Rapeseed and sunflower account by weight for $90 \%$ of processed oilseeds in France, which has a dozen factories with a total annual capacity (reached in 2008) of approximately 5 million tons of seeds. These plants arrive by road, rail, sea or inland waterway. For soybean, conventional crush- ing is concentrated on a single factory whose annual capacity is $500000 \mathrm{t}$ from imported seeds (Fig. 8).

\section{Seed storage}

Commercial norms require that rapeseed must have less than $9 \%$ of water content, fewer than $2 \%$ of impurities and an oil content above $40 \%$. Sunflower seeds have to have the same characterisitics for water content and impurities; the oil content must be above $44 \%$ and the oleic acidity below $2 \%$. 
F. Fine et al:: OCL 2015, 22(3) A302

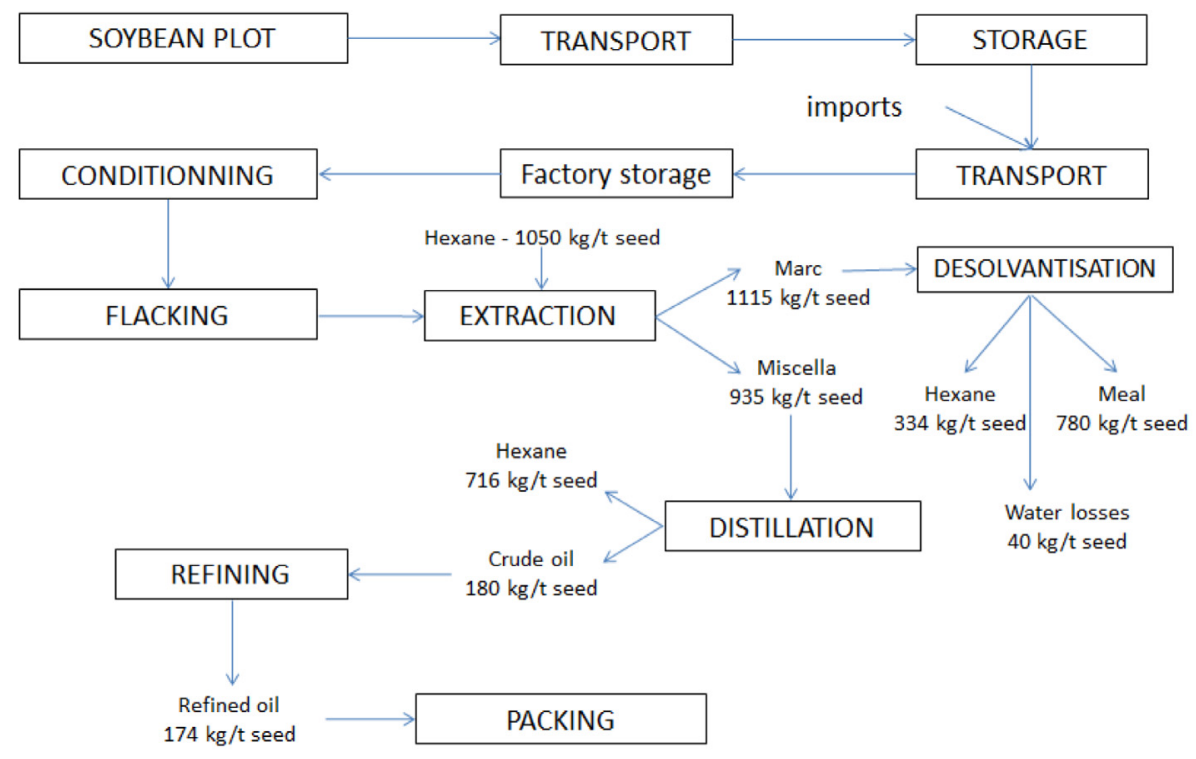

Fig. 6. Description of soybean crushing process with the mass balance for one ton of seeds.

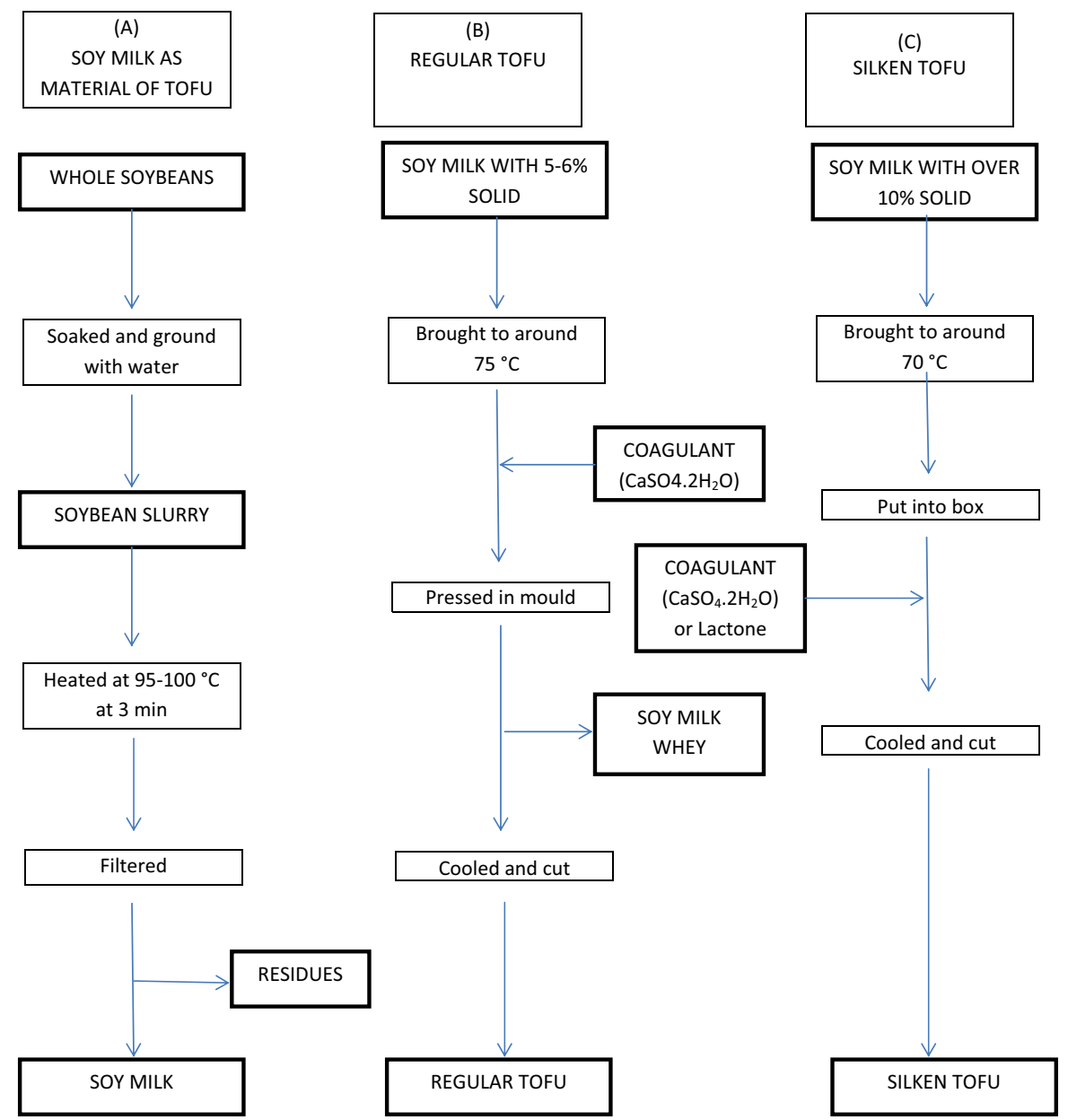

Fig. 7. Tofu manufacturing process diagram. Source: Fukushima (1981). 


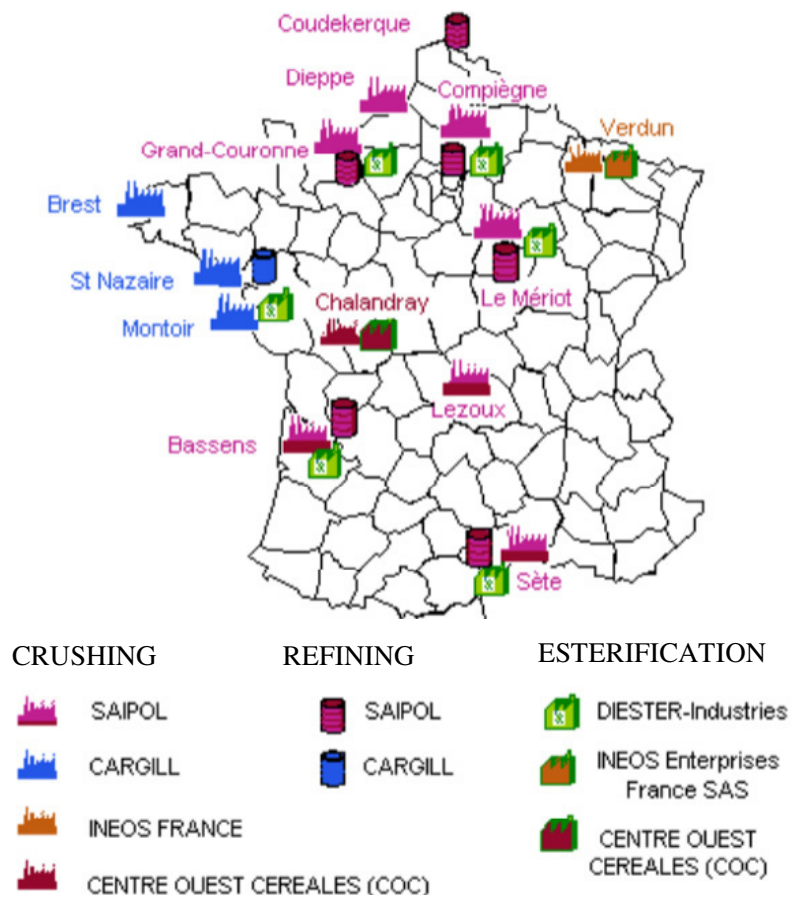

Fig. 8. Main crushing, refining and esterification factories in France.

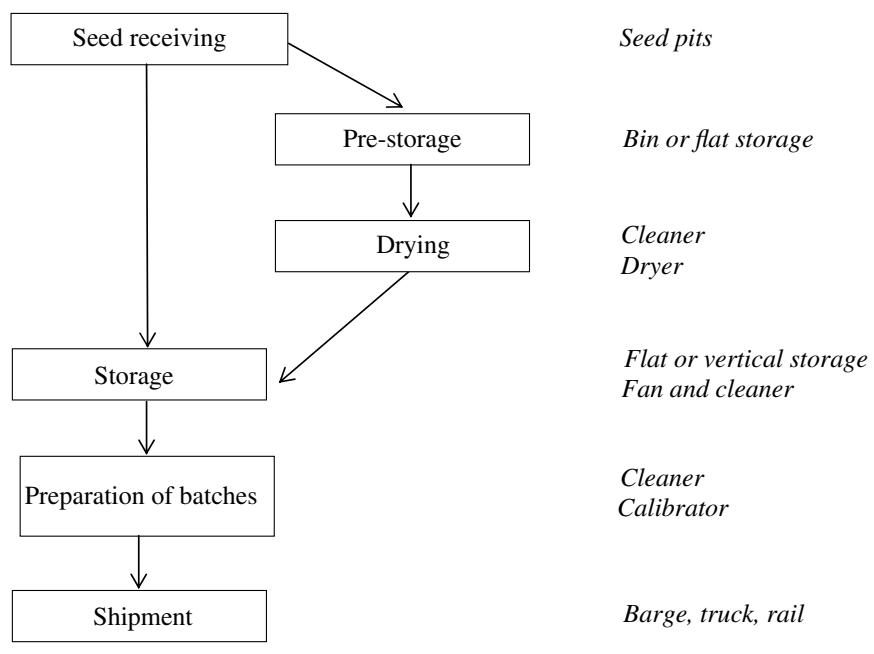

Fig. 9. Description of unit operations performed during the seed storage.

In order to preserve these seed qualities, several steps are required. They are set out in Figure 9. Moving from one step to another involves a separate handling operation. These handling operations can also be carried out on the occasion of a bin transfer, an operation to optimize the storage placings or a specific operation on the stored grain itself.

Before drying and storage, sunflower seeds and rapeseeds have to be carefully cleaned by sieving in order to remove impurities. In order to avoid oil acidification, the development of insects and the propagation of moulds, these seeds have to be dry (close to $7-8 \%$ humidity) and cool (below $10{ }^{\circ} \mathrm{C}$ ) (Fig. 9).

\section{Oilseed crushing}

For rapeseed and sunflower oil extraction, industries employ and even combine mechanical (pre-press) and solvent extraction methods. Following an industrial process, residual oil content in rapeseed and rapeseed meal will be around $2 \%$ (Allaf et al., 2014)

Prior to the oil extraction process, oilseeds require varying degrees of seed preparation. Seed cleaning, drying, grinding, hull removal, cooking, flaking and extruding are all potential unit processes involved in seed preparation.

Cleaning aims to remove the foreign material such as weed seeds, sticks, pods, dust, soil, sand, stones and stray metal. Magnets are used to remove the iron-based materials. Plant debris and dust are typically lighter than oleaginous materials. Removing this foreign material from the seeds stream therefore typically involves a combination of course screening followed by aspiration. This combination of processes is commonly referred to as scalping. Soybeans are typically reduced in size using an apparatus known as a cracking mill. These mills generally consist of two sets of cylindrical corrugated rolls in series. The rolls operate at differential speeds in order to facilitate the breaking apart of the oleaginous materials. Sunflower seeds are broken in impact dehuller prior to hull removal. In order to minimize the production of fines that are difficult to separate from the hulls during downstream sorting these apparatus are designed to cause multiple impacts. A popular design is based on large squirrel cage rotor turning in front of a specific stator.

Soybeans and sunflower kernels are surrounded by a high fiber and low oil content fraction called a hull. Removing this fraction reduces the volume of material to undergo extraction and results in the defatted meal having a higher protein content. Decortication or dehulling occurs after the seedbreakage described above. In a first stage, hulls are separated from the meats (kernels) fraction by aspiration or by flotation in a counter flow airstream. Small particles of meats become attached to the hulls; they are recovered by different combinations of agitation and screening in order to avoid large losses of oil. Effective soybean dehulling results in hulls with less than $1.5 \%$ oil content and meats with less than $3.5 \%$ of hulls.

Except in the case of cold pressing, oilseeds are generally heated and sometimes dried prior to their extraction. This important step can be referred to as 'conditioning' when the heating time is short (10-15 $\mathrm{min})$ and the maximum temperature does not exceed $70-80{ }^{\circ} \mathrm{C}$. It is referred to as 'cooking' when the heating time is longer and the temperature higher. Conditioning precedes the flaking step and aims at softening the seeds in order to reduce the work of the flaker and to improve oil extractability. The source of heat is indirect steam: the principle of conditioning is to facilitate the transfer of heat from saturated steam to the oilseed without allowing the steam to enter into contact the material being conditioned. It is possible to distinguish three main types of conditioners/cookers according to method used to facilitate contact between the seeds and the walls of the vessel containing the steam. The most recent was introduced by Solex Termal Science and consists in passing the seeds between large double-walled plates containing steam. The plates are set vertically and are spaced $10 \mathrm{~cm}$ apart, thus allowing the seeds to flow downwards by gravity. 
This design minimizes the mechanical energy required to force the seeds into contact with the warm metal and permits the use of a lower temperature of fluid than under other systems. Another popular design is a large horizontal drum fitted with a numerous steam pipes against which the seeds enter into contact. Though this conditioner requires mechanical energy to ensure the seeds' agitation heat transfer is relatively fast and efficient due to the relatvely large surfaces areas of warm metal available for heat exchange. The oldest design is called a stack cooker and consists of a vertical serial of flat trays heated by steam on which the seeds are energetically stirred to facilitate their contact with the metal. Since the volume-surface ratio is larger than in the previous apparatuses, a considerable amount of mechanical energy is required to force the heat exchange.

Cooking is a stronger treatment than conditioning and leads to a significant modification in the seed structure. The main consequence concerns the coagulation of proteins, especially the oleosins which stabilize the oil bodies in the cells. Consequently, the cellular compartmentalization of oil droplets is disrupted and the oil availability improved. Molecular agitation decreases oil viscosity and generates some exudation of oil visible on the surface of the flakes. Heat also decreases oil viscosity and reduces of water content. Concerning the mechanical expression of oil from rapeseed, cooking reduces threefold the amount of press energy required.

Flaking is performed on solvent-extracted seeds. The operation consists in flattening the conditioned material between two smooth rolls that turn in opposite direction and are forced together by hydraulic cylinders. Good extraction, especially for seeds going directly to extraction, requires thorough flaking because insufficiently flaked particles will not be accessible to the diffused solvent and the oil they contain will remain inextractible.

Extrusion with expanders is commonly used for the preparation of soybeans. The principle of the operation is to improve the quality of the oil by inactivating the D-phospholipase responsible for the formation of non-hydratable phospholipids and to improve the efficiency of the extraction by transforming low density flakes into denser collets. This densification increases the capacity of the extractor by enabling more oilseeds to be packed into it. The process is based on possibility of bringing the flakes into direct contact with steam at above atmospheric pressure in a first step followed by a pressure drop at the exit of the machine which ensures a brisk vaporization of moisture, thereby giving the collets a porous structure.

Mechanical extraction can be used both as unique extraction technique and in combination with solvent extraction. The principle of mechanical extraction consists in squeezing the oil-bearing material in a device fitted with a porous surface allowing the solid to concentrate and the liquid to exit. Continuous pressing is done in screw press that is compresses the cake by forcing its progression into a volume in constant diminution. For this, the shaft of the screw has an increasing diameter. This screw is surrounded by a slotted cage that allows air and oil to leave the area under greatest pressure. The width of the slots is adapted to the pressure and to the oil flow. A good separation of solid and liquid requires that the cage porosity be both sufficiently large for the oil to flow and sufficiently small to maintain the solid under pressure inside. Oilseed preparation is critical because adjustments to temperature, extent of cooking and moisture content influence cake plasticity, oil viscosity and cake porosity. When mechanical extraction is not followed by solvent extraction, cooking is generally stronger and the drying more intense. Double pressing, i.e., cold pressing followed by cooking and second pressing gives rapeseed cakes with a 9-10\% oil residue. A single full press gives slightly more fatty cakes $(10-12 \%)$. Cold pressing produces rapeseed cake with 12 to $25 \%$ of oil, depending on the capacity and quality of the press. In large oil mills using solvent extraction, mechanical extraction removes up to $70 \%$ of the seed oil but this is just considered as a preparatory step because from the quality of the cake depends the efficacy of the extraction. Pre-press produces a cake with 18 to $22 \%$ oil content. The cake must have good permeability in order for the solvent to penetrate among the particles and percolate with ease.

Solvent extraction has the benefit of producing higher extraction yields than achieved with mechanical extraction. Around the world commercial hexane is the most commonly used solvent for oilseed solvent extraction. In the solvent extraction process, the miscella at the surface of the oleaginous material diffuses through the cell walls to the oil bodies located within the cells. The miscella and the oil bodies quickly become a solution. The gradient of oil concentration in the miscella is the driving force leading to the exhaustion of the solid material. So, the principle of continuous extraction is to maintain this gradient of concentration by adding fresh solvent on the material in a counter-flow circulation. At the end of the extraction, the solid is soaked with hexane that is removed in a desolventizer by heat action, as in a vertical cooker or by direct steam which strips the solvent from the meal. The desolventization of the meal plays an important role in its feed value because in presence of heat and moisture, certain antinutritional factors like the trypsin inhibitor of soybean can be destroyed but on the other hand excessive toasting could result in the loss of sensitive amino-acids such as lysine which have an amine function that can react with reducing sugars to form the first compound of the Maillard reaction. The oil from the miscella is recovered by evaporating the solvent under a vacuum, with the solvent being condensed and returned to the extractor.

\section{Refining}

The purpose of refining edible oils and fats is to remove free fatty acids and other undesirable substances, including impurities, while maintaining the nutritional value and ensuring the quality and stability of the end product. Thus industrial customers have an input that conforms to precise and complete specifications and the end-consumer are provided with a refined product that meets their expectations (for example, oil that is clear, has a consistent taste and is stable). The goal of the refining step is to remove phospholipids (degumming), free fatty acid (neutralization), pigments (discoloration), waxes in the case of sunflower (dewaxing) and odorous compounds (deodorization). Possible contaminants (pesticides, heavy metals) are also eliminated. There are two main refining processes used on crude oils: chemical/alkali refining and physical refining. They differ principally in the way free fatty acids are removed. Refining also enables hexane to be removed to an undetectable level. The different unit operations are performed 
continuously, with the refining facilities treating all types of oil by adapting the operating conditions.

\section{Packing}

After refining, vegetable oils are generally filtered before packing. The packaging varies according to the customers' specifications. Oil, for example, can be packaged in small vials, bottles or containers. A large range of packaging materials can be used for conditioning oils (glass, PET etc.). This conditioning can be performed directly on the oil production site, or at a site dedicated entirely to this activity. During this conditioning, mixtures of oils can be made.

\section{Supplying}

There are only a few companies in France that engage in crushing: Saipol, Cargill, INEOS and Huileries Lapalisse. Regarding the refining, the business is limited essentially to Cargill and Saipol. Refining activities tend to be linked to crushing and are located in the port sites.

The concentration of the oil mill industry is also reflected in the packaging and marketing companies, with Lesieur and Cargill being by far the most important, and Lapalisse being the other much smaller yet significant player.

\subsection{TOFU}

Basic regular tofu is a white, soft, essentially bland product that closely resembles pressed white milk curd. Its production starts with the preparation of soymilk. Soybeans are boiled and then cooled to around $75^{\circ} \mathrm{C}$. The thin protein-lipid film (surface scum) formed on the surface of the milk is removed. A coagulant, consisting of slurry of gypsum powder or a solution of magnesium salts (also called nigari) is then added. Curdling occurs. The free supernatant whey is removed and the curd is transferred to perforated boxes and pressed until a coherent block of curd is obtained. The curd is then immersed in cold running water for several hours, with the object of cooling and leaching out excess coagulant and entrapped whey solids. The block is then cut to retail-size portions and wrapped for selling. Fresh tofu is stored, transported and sold as a refrigerated perishable. An analogy can be drawn between tofu production and cheese manufacture.

A radically different method is used for the industrial production of "silken tofu", a softer and more fragile type of bean curd. Here the production process resembles more that of yogurt than of cheese. Soymilk with a high solid content $(10 \%$ rather than the $5-6 \%$ in regular tofu) is heated to $100{ }^{\circ} \mathrm{C}$, then cooled to room temperature. Glucono-delta-lactone (GDL) is then added and the milk is poured into the retail containers. After sealing, the filled containers are heated in a water bath at $80-90{ }^{\circ} \mathrm{C}$ for 40 to $60 \mathrm{~min}$. At this temperature, GDL is converted into gluconic acid, which induces protein coagulation as a homogeneous gel, with no whey separation.

Prepared in this way, silken tofu is a pasteurized product that under refrigeration keeps well for a few days.

A diagram outlining the manufacturing processes of regular and silken tofu is presented in Figure 7. The first part of a tofu factory is, actually, a soymilk (also called tonyu) plant where 1 ton of seeds can give 80001 of tonyu and 1.3 tons of solid residue (called okara). The second half of a tofu factory comprises the coagulation, curd washing and finishing operations where 3 tons of tofu can be obtained from 1 ton of soybean seeds.

A variation of the process described above is used for the production of long shelf-life silken tofu, using UHT technology. Soymilk with $10 \%$ solid content is heated to $130{ }^{\circ} \mathrm{C}$ and cooled to room temperature in a continuous aseptic fashion. The GDL solution is cold-sterilized by filtration and injected into the stream of the sterilized, cooled soymilk. The mixture is aseptically filled into plastic containers. The sealed containers are subjected to heating, as described below. Aseptically filled tofu keeps well for several months without refrigeration.

\section{Collected data}

\subsection{Different types of identified food losses}

In this study, the following losses were initially included:

- Seed losses immediately prior to harvest and at harvest when combining.

- Seed losses during transportation and storage.

- Oil losses when crushing (constraints encountered when extracting oil for some seed lots).

- Losses in processing tofu.

- Losses when supplying (breakages, expiry date exceeded...) which were estimated to be negligible.

\subsection{Determinant factors of food loss (technical, economic, organisational, regulatory etc.)}

Just before harvest, rapeseed losses occur due to pod shattering linked to the presence of birds, specific climatic conditions (wind, hail, rain; a risk scale per region and a map of detrimental climatic conditions are available), sanitary status of the crop and the genotype of the variety (very significant effect). It seems that seed quality (acidity etc.) and crushing ability are not modified, but this needs to be confirmed. In the case of sunflower, losses are mainly due to bird damage to capitulums. Shattering in soybean is genotype-dependent. Some varieties appeared to be very susceptible to shattering.

At harvest: in rapeseed, losses are linked to crop lodging, heterogeneity of the crop, pod dehiscence, stem maturity (it is recommended that harvest be carried out at $9 \%$ humidity and not at 14\%), machine set-up (grader speed, progression speed of the machine etc.) and more or less suitable combine equipment (vertical cutters); in soybean, losses are due to pods being too near the soil to be mechanically harvested (use of soft cutter bars) and to the heterogeneity of the crop.

During transportation: seed leakage, which is negligible during loading, transportation and unloading, is directly connected to seed size.

During seed storage: seeds are dry, so the possibility to degrade seed lots is very limited. Storage is easy and consequently losses are low. Refusals of seed lots by crushers are mainly due to the presence of impurities. Such seed lots are sorted again by the storage facility before crushing. 
Table 2. Percentage of food losses of the French oilseed sector (rapeseed, sunflower and soybean oils, and tofu).

\begin{tabular}{|c|c|c|c|}
\hline \multirow{2}{*}{ Products } & \multicolumn{3}{|c|}{ Food losses (\%) } \\
\hline & Harvest & Transportation and storage & Processing \\
\hline Rapeseed oil & 5 & 1.5 & 3.7 \\
\hline Sunflower oil & 2 & 1.5 & 3.7 \\
\hline Soybean oil & 6 & 1.5 & 3.3 \\
\hline Tofu & 6 & 1.5 & 1.1 \\
\hline
\end{tabular}

Seed storage at the farm, on flat platforms without ventilation, is well managed. But losses can be higher than at the storage facility.

During crushing and packing: The margin for the crusher is very low, so the industrial process is optimized to minimize possible losses (residual oil content less than $1 \%$ in the meal). The extraction process can be adapted to the traits of each seed lot, which limits oil content in the meal. Dehulling can induce oil losses, but fatted hulls can be valuable for other markets. The principal losses are observed when extracting oil by pressure or during oil filtration. Scope for improvement in this area appears to be limited. The risk of oil contamination during the process is also very low.

Losses during refining are mainly found in the soapstocks, the used bleaching clays and waxes (e.g. sunflower). The packaging of refined oil is directly managed by the crusher on the same site, which limits the risk of losses. Losses during supplying are also very limited because oil is processed for longterm conservation in the home.

\section{Estimation of oil food losses into the French oilseed chain}

\subsection{Losses expressed in percentages at different stages of the oil process (Table 2)}

\section{At harvest (Table 3).}

During transportation and storage: losses were estimated to be around $1.5 \%$.

But sunflower losses at harvest and during transportation are expected to be lower than for rapeseed.

\section{During crushing and packing:}

- rapeseed: one ton of seeds contains $440 \mathrm{~kg}$ of oil; after crushing, $435 \mathrm{~kg}$ of crude oil and $549 \mathrm{~kg}$ of meal containing $1 \%$ of residual oil (5.5 kg of oil) are produced from one ton of seeds. After refining, $419 \mathrm{~kg}$ of oil are collected. The crushing yield is therefore $98.8 \%$ and the residual oil is exclusively recovered inside the meal. The oil yield after refining is $95.2 \%$;

- sunflower: one ton of seeds contains $448 \mathrm{~kg}$ of oil; after crushing, $434 \mathrm{~kg}$ of crude oil and $404 \mathrm{~kg}$ of meal containing $1 \%$ of residual oil $(4.1 \mathrm{~kg}$ of oil) are produced. After refining, $418 \mathrm{~kg}$ of oil are collected. The crushing yield is therefore $96.8 \%$ and the residual oil is mainly recovered inside the meal. The oil yield after refining is $93.3 \%$;
- soybean: one ton of seeds contains $195 \mathrm{~kg}$ of oil; after crushing, $180 \mathrm{~kg}$ of crude oil and $780 \mathrm{~kg}$ of meal containing $1 \%$ of residual oil $(7.8 \mathrm{~kg})$ are produced. After refining, $174 \mathrm{~kg}$ of oil are collected. The crushing yield is therefore $92.3 \%$ and the residual oil is mainly recovered inside the meal. The oil yield after refining is only $89.2 \%$;

- linseed: linseed is not crushed in France. The refining yield is around $98 \%$. Linseed oil is mainly imported from VandePutte in Belgium.

\subsection{Quantitative losses in tons of total production (Table 4)}

Only the oil yield before refining was used for calculation, due to the fact that residual oil remaining in the meal is valuable for feed and cannot be strictly considered as a loss.

Consumption of $16.7 \mathrm{~kg}$ of vegetable oil per habitant and $1000 € / T$ of oil were used as reference data for the calculations.

- Rapeseed: 3.558 MT $\times 31 \%$ are crushed for food $=$ $1.103 \mathrm{MT}$.

At harvest: $5 \%$ loss: $(1.103$ MT: $0.985: 0.95 \times 0.05 \times$ $0.435)=25.6 \mathrm{KT}(50.6 \%)$.

During transportation and storage: $1.5 \%$ loss: (1.103 MT: $0.985 \times 0.015 \times 0.435)=7.3 \mathrm{KT}(14.4 \%)$.

During refinery: $3.7 \%$ loss: $(1.103 \mathrm{MT} \times(1-0.963) \times$ $0.435=17.7 \mathrm{KT}(35.9 \%)$.

In total: $50.6 \mathrm{KT}$ crude oil, or $9.8 \%$ of the potential oil production (50.6: $(1.103$ : 0.985:0.95 $\times 0.435)$ ), or 116.3 KT of seeds; or $50.6 \mathrm{M} €(50.6 \times 1000 \mathrm{~kg} \times 1000 €)$; equal to the annual consumption of 3029940 people $(50.6 \times$ $1000000: 16.7)$; the remaining residual oil $(1 \%)$ in the meal represents $6.0 \mathrm{KT}(1.103 \mathrm{MT} \times 0.549 \times 0.01)$.

- Sunflower: $1.458 \mathrm{MT} \times 31 \%=452 \mathrm{KT}$ are crushed. At harvest: $2 \%$ loss: $(452 \mathrm{KT}: 0.985: 0.98 \times 0.02 \times 0.434)$ $=4.1 \mathrm{KT}(28.7 \%)$.

During transportation and storage: $1.5 \%$ loss: (452 KT: $0.985 \times 0.015 \times 0.434)=3.0 \mathrm{KT}(21.0 \%)$.

During refining: $3.7 \%$ loss: $(452 \mathrm{KT} \times(1-0.963) \times 0.434=$ $7.2 \mathrm{KT}(50.3 \%)$.

In total: $14.3 \mathrm{KT}$ of crude oil, or $7.0 \%$ of the potential oil production (14.3: (452: 0.985: $0.98 \times 0.434)$ ), or $32.9 \mathrm{KT}$ (14.3 KT: 0.434$)$ of seeds; or $14.3 \mathrm{M} €(14.3 \times 1000 \mathrm{~kg}$ $\times 1000 €$ ); equal to the annual consumption of 856.287 people $(14.3 \times 1000000$ : 16.7$)$; the remaining residual oil $(1 \%)$ in the meal represents $1.8 \mathrm{KT}(452 \mathrm{KT} \times 0.404 \times$ 0.01).

- Soybean for oil: 587 KT of seeds are crushed (20\% produced in France and 80\% imported).

Losses at harvest from production outside France were not included ( $80 \%$ of the seed crushed).

At harvest: $6 \%$ loss: $(587 \mathrm{KT} \times 0.20$ : 0.985: $0.94 \times 0.06 \times$ $0.180)=1.4 \mathrm{KT}(21.5 \%)$.

During transportation and storage: $1.5 \%$ loss: $(587 \mathrm{KT}$ : $0.985 \times 0.015 \times 0.180)=1.6 \mathrm{KT}(24.6 \%)$.

During refining: $3.3 \%$ loss: $(587 \mathrm{KT} \times(1-0.967) \times 0.180=$ $3.5 \mathrm{KT}(53.8 \%)$. 
Table 3. Seed losses (kg/ha and \% of the expected production) at harvest of the French oilseed sector (rapeseed, sunflower and soybean).

\begin{tabular}{cccccccc}
\hline & \multicolumn{3}{c}{ Total losses } & \multicolumn{3}{c}{ Losses at three steps } \\
\hline Species & Minimum & Mean & Maximum & & Minimum & Mean & Maximum \\
\hline Rapeseed & 40 & 175 & 550 & Shatterring & 0 & 15 & 50 \\
& $1 \%$ & $5 \%$ & $13 \%$ & Cutting & 10 & 80 & 300 \\
& & & & Threshing & 30 & 80 & 200 \\
Sunflower & 30 & 80 & 500 & Shatterring & When disease damages \\
& $1 \%$ & $2 \%$ & $15 \%$ & Cutting & \multicolumn{3}{c}{ When lodging } \\
& & & & Threshing & 20 & 30 & 200 \\
Soybean & 50 & 400 & 600 & Shattering & Unusal (varietal trait) \\
& $1 \%$ & $6 \%$ & $18 \%$ & Cutting & 40 & 300 & 580 \\
& & & & Threshing & 10 & 15 & 20 \\
\hline
\end{tabular}

Table 4. Quantitative food losses (KT) of the French oilseed sector (rapeseed, sunflower and soybean oils, and tofu).

\begin{tabular}{ccccc}
\hline \multirow{2}{*}{ Product } & \multicolumn{4}{c}{ Food losses (KT) } \\
\cline { 2 - 5 } & Harvest & $\begin{array}{c}\text { Transportation } \\
\text { \& storage }\end{array}$ & Processing & Total \\
\hline Rapeseed oil & 25.6 & 7.3 & 17.7 & 50.6 (oil) \\
Sunflower oil & 4.1 & 3.0 & 7.2 & 14.3 (oil) \\
Soybean oil & 1.4 & 1.6 & 3.5 & 6.5 (oil) \\
Tofu & 2.6 & 0.3 & 0.5 & 3.4 (seeds) \\
\hline
\end{tabular}

In total: $6.5 \mathrm{kT}$ of crude oil, or $6.0 \%$ of the potential oil production $(6.5:((587 \times 0.80: 0.985 \times 0.180)+(587 \times$ $0.20: 0.985: 0.94 \times 0.180))$, or $36.1 \mathrm{kT}(6.5 \mathrm{KT}: 0.180)$ of seeds including $13.4 \mathrm{KT}$ of metropolitan seeds; or $6.5 \mathrm{M} €$ $(6.5 \times 1000 \mathrm{~kg} \times 1000 €)$; equal to the annual consumption of 389.221 people $(6.5 \times 1000000: 16.7)$; the remaining residual oil $(1 \%)$ in the meal represents $4.6 \mathrm{KT}(587 \mathrm{kT} \times$ $0.780 \times 0.01)$.

- Soybean for tofu: $104 \mathrm{kT} \times 40 \%=41.6 \mathrm{KT}$ of seeds are produced in France for tofu supply:

At harvest: $6 \%$ loss: $(41.6 \mathrm{~T}: 0.94 \times 0.06 \times 1)=2.6 \mathrm{kT}$ (76.4\%).

During transportation and storage: $1.5 \%$ loss: $(41.6 \mathrm{kT} \times$ $0.015 \times 1)=0.3 \mathrm{kT}(8.8 \%)$.

During seed processing: $1.1 \%$ loss: $(41.6 \mathrm{kT} \times(1-0.989))=$ $0.5 \mathrm{kT}(14.7 \%)$.

In total: $3.4 \mathrm{kT}$ of metropolitan seeds or $8.2 \%$ of the potential tofu production, for seeds with $7 \%$, tofu with $78 \%$ and Okara with $80 \%$ water content, one ton of seeds produces 3 tons of tofu and $1.3 \mathrm{~T}$ of Okara, equivalent to $3 \times(1-0.78)$ : $0.93+1.3 \times(1-0.80): 0.93=0.989 \mathrm{~T}$ of seeds which match with a $98.9 \%$ yield.

Therefore, total oil losses from harvest to supplying are around 71.4 kT, equivalent to $10 \%$ of total oil consumption in France.

\section{Discussion}

\subsection{General constraints encountered when collecting data}

Very few published data are available on oilseed food losses. In fact, data only on losses at harvest for rapeseed and soybean and along the tofu process for soybean have been published. Our data were mainly collected from professionnal experts through their institution or company (CETIOM, SAIPOL, CREOL) for oil. So for conducting this type of analysis it appears necessary to seek the data directly, mainly from professionnal organisations, and to exploit network connections between the various actors. However, expert sources are limited for relatively small French sectors like for olive oil. For this sector, gathering directly the necessary information appeared to be impossible. Raw olive data need to be produced. All of France's palm oil is imported directly. For that reason this oil sector was not included in our analysis; and likewise for linseed: given that most of the seed is crushed outside France, we considered there are no food losses for linseed in France.

\subsection{At harvest}

\section{Just before harvest}

Rapeseed pod shattering at maturity: farmers are often afraid of shattering mature rapeseed pods. The consequences are volonteers under the crop at the harvest. If only a few grains fall on the soil, they can quickly produce very demonstrative little plants.

Crop phytosanitary protection diminishes both pod shattering and failure to ripen. However, it seems that general cultivation conditions: wet soil, rainy conditions before harvest or birds and insects do have effects on pod shattering.

On the other hand, breeders produce new varieties with better shattering resistance. Testing this trait among the new commercial varieties has commenced in order to classify them.

Moreover pod shattering at maturity is not the main reason for losses in rapeseed. 
Birds' damages on sunflower capitulums: for sunflowers, if the harvest takes place in good conditions, the loss of grains is almost non-existant.

Sometimes a capitulum escapes from the combine but no more happens. On the other hand, locally it is possible to observe some damage just before the harvest on sunflower capitulum. Birds start causing damage when the grains have a high moisture level. Then, the damage will be serious but very localized to one part of one field.

Such losses were included in the study.

\section{At harvest}

Rapeseed: for straight combining, the harvesting period is very difficult to define and is often too early. The reason for this is not only that rapeseed has an extended flowering period of 3-4 weeks, but that the maturation is also uneven and stretched. The optimal period of maturation is the period when the lower branches along the stem, the ripe pods and the stem itself have dried up to the desired state.

Losses at the reaper assembly: mounting an adapter that elongates the floor of the reaper assembly is a very good means of reducing seed losses at the front of the combine harvester. In fact, the close positioning of the cutting mechanism and the feeding screw is one of the most important causes of loss. Unless there is space between the feeder and the cutting blade, it is difficult to cut rape plants that have lots of branches and delicate pods.

Seeds are lost on the field during mass transfer to the middle part of the header. During the cut, some seeds are irrevocably lost. First, some are shredded at the cutting blade or on top of it. Then, others are knocked out by the energetic action of the seed sweep and the feeder fingers.

The depth of the header extension is important. Even if there exist a wide range of rapeseed header extensions the one chosen must be sufficiently deep that the fingers of the helical conveyor do not eject the grains out.

The efficiency depends on the extension size. The largest are $800 \mathrm{~mm}$ deep.

Losses in treshing and cleaning in the combine are as important as losses at the front of the combine. Different ways exist to reduce these losses.

The harvesting date is currently determined by the grain moisture $(9 \%)$ but very often, the vegetative parts of plants are green. Some varieties have become phoma resistant; the stems stay green until harvest without disease. In the combine, green stems mixed with dry pods and grains engender losses. The blown air has difficulty in traversing the sieve and separating the dry seeds from the humid and heavy straw; the grains are not sorted out and come out of the machine with the straw.

In this case, it is necessary to postpone the harvest date until complete maturity and totally dry straw. The new varieties which are more shatter resistant permit a longer wait before harvest.

But if weather conditions are not favorable when the deadline is reached, it is necessary to harvest with green stems and to cut just below the seed pods in order to prevent the green straw from entering the combine.

However, from the cockpit, it is hard to clearly distinguish the height of the reaper from the vegetation.
It will be possible in future to install a video camera near the cutting knife of the reaper and thereby adjust automatically the height of the reaper under the pods, thereby leaving the green stems in the field. Frequently, the recommended height is nearly $800 \mathrm{~mm}$.

Moreover, to cut plants higher is an effective means of reducing the straw volume in the combine and so improves the combine's performance. The main stem volume $(0$ to $0.80 \mathrm{~m}$ from the soil) is $40 \%$ of crop volume. The other part with thin stems with pods ( $>0.80 \mathrm{~m}$ from soil) is not more than $60 \%$ of crop volume. At present, farmers cut their crop nearly $0.30 \mathrm{~m}$ off the soil.

Sunflower harvest: the period between maturity and harvest should be kept as short as possible in order to minimize losses from bird damage and head-rot diseases.

In a lodged sunflower, use a crop header helps avoid capitulums losses. Moreover, a crop header can be used without reaper modification. Harvesting extremely dry seeds can drive up the loss level. Therefore combine speed must be reduced accordingly.

Soybean harvest: cut soybeans as low as possible to minimize stubble losses. Excessive stubble heights can result in significant losses (Beasley, E.O. 2013).

Special equipment exists to help prevent major losses. When harvesting soybean close to the ground, maximum flexibility is needed in the header. The flexible cutting knife of this reaper assembly must automatically adjust to the changing ground contours. A flexible reaper boosts combine productivity. So, this type of reaper can be used in small grains if the header is locked on the rigid position.

In fact, for rapeseed, if the annual national yield varies between $2.9 \mathrm{~T} / \mathrm{ha}$ and $3.7 \mathrm{~T} / \mathrm{ha}$, we have a yield variation of $0.8 \mathrm{~T} / \mathrm{ha}$ max for a level of losses each year of $0.4 \mathrm{~T} / \mathrm{ha}$. For sunflower and soybean, like rapeseed, the yield variation is higher than losses: $0.5 \mathrm{~T} /$ ha for $0.3 \mathrm{~T} /$ ha.

In each case, the level of losses is significant compared with yield fluctuation, but lower.

\subsection{During transportation and storage}

On an annual domestic production of grains and seeds of around 70 million tons (total grain, oilseed and protein-seed) less than $15 \%$ is self-consumed directly on the farm; the balance of about 60 million tons is marketed to downstream firms (first processing, export) through the network of collectors. No published data is available on this topic: this is why data were mainly collected from professionnal experts. The amount of handling during storage also determines the level of losses. Although the storage time is relatively short, storage-related losses amount to about $1 \%$.

\subsection{During crushing and refining}

Data reflect our experts' experience at their institution or industrial plant. The oilseed extraction process, having undergone numerous technical improvements and optimizations over the past few decades, has achieved very good reductions in losses (Fine et al., 2013). For crushing oilseeds, it has been established that there is no technology whose performance 
is comparable to that employing hexane. It has been recommended that $\mathrm{R} \& \mathrm{D}$ programs set up notably on less volatile renewable solvents.

The use of softer crushing process conducive to preserving protein digestibility in monogastric feed would lead to more fatty meal with more residual oil but still easy to use in animal feed. Any new process for producing a meal, without the use of hexane, with up to $5 \%$ residual oil could be adopted by industrial users.

To significantly reduce refining losses, there is a need to develop soft refining methods and to make more coloured and more fragrant oils acceptable to consumers. In the event that the crude oil would be less abundent in undesirable compounds that have to be removed during the refining process, there would be scope for studying a less harsh refining process:

- Reduced non-hydratable phospholipids: ability to prevent acid conditioning;

- Less chlorophyll: reduction or elimination in the consumption of bleaching earth;

- Less free fatty acids: removal neutralization;

- Fewer contaminants: decreased consumption of additives such as activated carbon, reducing the temperature of deodorization.

This reduction in the number and/or intensity of refining steps would reduce the impact of the processes on the oil and result in:

- a decrease in production costs (less consumption of energy, inputs, less waste oil etc.);

- improved preservation of micronutrients during the refining process (tocopherols, coenzymes, sterols etc.);

- better preservation of the oils' oxidative stability (including without fading), and especially;

- reduced refining losses.

Remark: for oilseed crops, crushing with hexane produces a meal with $1 \%$ residual oil whereas the mechanical extraction performed at the farm level is producing a meal with a $15 \%$ residual level. But this meal is very valuable for feed. That is the reason why for the purposes of this study residual oil in such a meal will not be considered as a loss.

\subsection{During supplying}

Depending on the type of customer, vegetable oils are packed in different packages ranging from plastic or glass bottle in households to one ton containers for industrial uses. These packages and the low water activity oils allow them to maintain themselves over long periods without giving rise to a microbiological hazard. Only the organoleptic qualities of oils can be altered by oxidation phenomena. Industrial expertise indicates that the smaller the packaging volumes, the higher the share of losses (bottom remaining container).

Concerning tofu, two cases are possible: silken tofu is a pasteurized product which keeps well for a few days under refrigeration and UHT tofu keeps well for several months without refrigeration.

\section{General conclusion and perspectives}

Most of the data had to be collected from professionnal experts due to the fact that the available published data concerned only losses at harvest. We show that the main areas of food oilseed losses are harvest (oil and tofu) and refining (oil).

Oilseeds and vegetable oils are easy to store but global losses from harvest to supply appear to be significant (around $71.4 \mathrm{kT}$ of crude oil, equivalent to $10 \%$ of the vegetable oil consumed annually in France). Compared to yield losses prior to harvest (estimated at around $12 \%$ in extreme conditions), food losses from harvest to supply are slightly lower. Losses are higher for rapeseed than for soybean or sunflower; this difference occurs mainly at the cutting and threshing steps.

There is room for improving the efficiency of the French oilcrop sectors, especially concerning the selection of varietal genetic traits (resistance to shattering in rapeseed or soybean, resistance to lodging in sunflower, upper basic pods in soybean etc.), the design of the combine harvester (adapted floor for the reaper, a camera to help adjust the height of the reaper, flexible reapers), and refining conditions. One important condition for loss reduction at refining would be that consumers accept more colourful and fragrant oils; achieving such a major change would need R\&D. Due to the relatively small amount of losses at post-harvest steps, it is difficult to imagine how to completely avoid or valorise such food losses in an economically profitable manner. In addition, fatted meals are easily used as feed in an economically viable way.

The unexpected results of this quantitative study demonstrate the potential value of extending this approach to other French oilcrop sectors (olives, for example) and to other countries to identify areas for improvement.

Besides quantitative losses, further research should also tackle qualitative losses, such as in nutritional quality. For example, soft refining processes have proven efficient in preserving the high nutritional qualities of oil (micronutrients etc.) and the residual meal used for food or animal feed (protein digestability). Further processing improvements could open the door to additional gains in the oils' nutritional value (micronutrients...). In future, estimating and reducing qualitative losses all along the chain could be undertaken to complete the quantitative approach, leading to an integrated approach towards more efficient oilcrop systems.

Acknowledgements. We kindly acknowledge Alain Laulan (SAIPOL, Place des Curins, 63190 Lezoux), Parick Carré (CREOL, 11 rue Gaspard Monge, 33600 PESSAC), Noémie Simon (ONIDOL, 11 rue Monceau, CS 60003, 75378 PARIS cedex 08), Morgane Estève-Saillard (FNCG, 66 rue de la Boétie, 75008 PARIS) for providing data and Thierry Chardot (INRA, UMR 1318, Inst. Jean Pierre Bourgin, 78026 Versailles, France), Zéphirin Mouloungui (UMR 1010 INRA/INPT - ENSIACET, 31931 Toulouse, France) for contributing to the discussion.

\section{References}

Allaf A, Fine F, Tomao V, Nguyen C, Ginies C, Chemat F. 2014. Impact of instant controlled pressure drop pre-treatment on solvent extraction of edible oil from rapeseed seeds. OCL 21: A301

Fine F, Abert Vian M, Fabiano Tixier AS, Carre P, Pages X, Chemat F. 2013. Les agro-solvants pour l'extraction des huiles végétales issues de graines oléagineuses. OCL 20: A502. 
Fukushima D. 1981. Soy Proteins for Foods Centering around Soy Sauce and Tofu. J. Amer Oil Chem. Soc. 58: 346-354.

Gustavsson J, Cederberg J, Sonesson J, van Otterdijk J, Meybeck A. 2011. Global food losses and food waste: extent, causes and prevention. FAO, Rome, 29.

Lipinski B, Hanson C, Lomax J, Kitinoja L, Waite R, Searchinger T. 2013. "Reducing Food Loss and Waste." Working Paper, Installment 2 of Creating a Sustainable Food Future. Washington, DC: World Resources Institute. Available online at http://www. worldresourcesreport.org.
Lundqvist J, de Fraiture C, Molden D. 2008. Saving water: from field to fork. Curbing losses and wastage in the food chain. Stockholm International Water Institute.

Sausse C, Wagner D, Lucas JL, Estragnat A, Mangenot O, Garric B, Raymond Reau R, Devaux C, Champolivier J, Messéan A. 2006. Estimation des pertes à la récolte du colza d'hiver (Brassica napus) dans des conditions variées. OCL 13: 431-438.

UNEP. 2009. The Environmental food crisis - The environment's role in averting future food crisis. United Nations Environmental Programme (UNEP), Nairobi.

Cite this article as: Frédéric Fine, Jean-Louis Lucas, Jean-Michel Chardigny, Barbara Redlingshöfer, Michel Renard. Food losses and waste in the French oilcrops sector. OCL 2015, 22(3) A302. 